\title{
Efektivitas ekstrak kayu ulin (Eusideroxylon zwageri) sebagai pengawet alami kayu terhadap serangan rayap tanah (Coptotermes curvignathus Holmgren)
}

\section{Ulin wood (Eusideroxylon zwageri) extract effectivity as natural wood preservatives to the attack of termite (Coptotermes curvignathus Holmgren)}

\author{
Desi Mustika Amaliyah ${ }^{\mathrm{a}, \star}$, Ratri Yuli Lestari ${ }^{\mathrm{a}}$, Mohammad Listianto Raharjo ${ }^{\mathrm{a}}$, \\ Saibatul Hamdia ${ }^{a}$ Budi Tri Cahyana ${ }^{a}$, Nurmilatina ${ }^{a}$ \\ ${ }^{a}$ Balai Riset dan Standardisasi Industri Banjarbaru \\ Jl. Panglima Batur Barat No. 2 Banjarbaru, Indonesia \\ *E-Mail: d351ma@gmail.com
}

Diterima 18 Oktober 2019, Direvisi 24 Desember 2019, Disetujui 27 Desember 2019

\begin{abstract}
ABSTRAK
Proses pengawetan kayu, umumnya menggunakan bahan kimia sebagai bahan pengawet. Bahan kimia yang seringkali digunakan sebagai pengawet kayu yaitu insektisida, heptachlor, chlordane dan HCS. Selain itu, pengawetan anti rayap dilakukan menggunakan asam borat, permethrin, kerosene (minyak tanah) imidakloprid. Penggunaan bahan kimia ini cukup berbahaya jika digunakan dalam konsentrasi tinggi. Pada industri pengolahan kayu, khususnya industri kayu ulin/kayu besi (Eusideroxylon zwageri) yang termasuk kelas awet I, menghasilkan limbah berupa serbuk gergaji yang jumlahnya cukup banyak dan belum termanfaatkan secara optimal yang dapat dimanfaatkan sebagai pengawet alami kayu. Tujuan dari penelitian ini adalah untuk meningkatkan daya awet kayu kelas awet rendah dengan memanfaatkan ekstrak limbah serbuk gergajian kayu ulin sebagai pengawet alami kayu kelas awet rendah. Tahapan dari penelitian ini adalah melakukan ekstraksi serbuk kayu ulin, pengujian ekstrak ulin menggunakan pelarut air, proses pengawetan kayu sengon dan kayu karet serta pengujian kayu yang telah diawetkan. Hasil yang diperoleh dari penelitian ini adalah semakin tinggi konsentrasi serbuk ulin dalam pelarut, rendemen ekstrak dan hasil uji fitokimia, nilainya cenderung mengalami penurunan dikarenakan kondisi larutan yang sudah jenuh. Berdasarkan uji fitokimia, ekstrak kayu ulin mengandung senyawa tanin, alkaloid, flavonoid, saponin, dan total fenolik. Pada uji ketahanan terhadap serangan rayap tanah (Coptotermes curvignathus Holmgren), ekstrak kayu ulin mampu menaikkan klasifikasi ketahanan hingga 2 (dua) tingkat, yaitu dari kelas IV menjadi kelas II, meskipun masih ada serangan pada kayu karet dan kayu sengon. Nilai uji mortalitas rayap tanah yang diumpankan ke kayu karet dan kayu sengon adalah sebesar $100 \%$ baik konsentrasi $5 \%$ hingga $20 \%$.
\end{abstract}

Kata Kunci : ekstrak, pengawet alami, kayu, ulin, rayap tanah.

\section{ABSTRACT}

In the wood preservation process, it is generally using chemicals as preservatives. Compounds that are often used as wood preservatives including insecticides, heptachlor, chlordane and HCS. Besides, anti-termite preservation is carried out using boric acid, permethrin, kerosene (kerosene) imidacloprid. These chemicals are quite dangerous if used in high concentrations. In the wood processing industry, especially the ulinwood/ironwood (Eusideroxylon zwageri) industry as the first durable class, produced a 
large amount of sawdust and has not been utilized optimally, that can be used as a natural wood preservative. This research aim was to increase the durability of low-grade wood by utilized the ironwood sawdust extract waste as a natural preservative of lowgrade timbers. The stages of this research were extracting ironwood powder, analyzing ironwood extract with water solvent, the preservation process of sengon wood and rubber wood and preserved wood testing. The finding obtained from this study was the higher the concentration of ironwood sawdust in the solvent, extraction yield and phytochemical test results tend to decrease due to the condition of the saturated solution. Based on the phytochemical analysis, ironwood extract contains tannins, alkaloids, flavonoids, saponins, and total phenolics. In the resistance test to termite attack (Coptotermes curvignathus Holmgren), ironwood extract was able to raise the classification of resistance to 2 (two) levels, namely from class IV to class II. However, there were still attacks on rubber wood and sengon wood. The value of termite mortality test for soil fed to rubber wood and sengon wood is $100 \%$ both concentration of $5 \%$ to $20 \%$.

Keywords : extracts, natural preservatives, wood, ironwood, termites.

\section{PENDAHULUAN}

Rayap merupakan salah satu jenis organisme perusak kayu yang sangat merugikan. Kerugian yang diakibatkan serangan rayap diperkirakan mencapai $\mathrm{Rp}$. 224-238 milyar tiap tahun. Salah satu jenis rayap di Indonesia yang sangat merugikan adalah rayap tanah (Coptotermes, $s p$ ) sebagai perusak kayu tanaman perkebunan seperti kelapa sawit, karet, coklat, dan pohon kelapa (Puteri, Jayuska, \& Alimuddin, 2016).

Selama ini upaya untuk pengendalian rayap tanah (Coptotermes sp.) dilakukan secara konvensional menggunakan senyawa kimia sintetik yang berupa pestisida anti rayap (termisida), diantaranya insektisida, heptachlor, dan chlordane. Selain itu, pengawetan anti rayap dilakukan menggunnakan asam borat, permethrin, kerosene (minyak tanah) imidakloprid. Akan tetapi penggunaan termitisida ini dapat berdampak negatif berupa pencemaran lingkungan, keracunan, bahkan kematian pada manusia (Wibaldus, Jayuska, \& Ardiningsih, 2016). Oleh karena itu, diperlukan upaya untuk pengendalian rayap ramah lingkungan sebagai alternatif bahan antirayap, salah satunya adalah dengan menggunakan senyawa metabolit sekunder dari ekstrak tumbuhan (Meidianto, Jayuska, \& Wibowo, 2019). Berbagai keuntungan dapat diperoleh jika menggunakan ekstrak kayu sebagai pengawet alami. Produk ini lebih aman daripada menggunakan pengawet sintetis karena resiko terhadap manusia lebih rendah dalam pengawetan kayu serta mengurangi residu racun, sehingga mampu meminimalkan pengaruh negatif terhadap lingkungan Da Silveira, Santini, Kulczynski, Trevisan, Wastowski, \& Gatto 2017).

Senyawa tanin merupakan salah satu komponen kayu yang mengandung senyawa polifenol tinggi dapat tahan terhadap serangan rayap dan jamur. Tanin merupakan salah satu senyawa metabolit sekunder yang dapat dijumpai pada hampir semua jenis tumbuhan hijau di seluruh dunia baik tumbuhan tingkat tinggi maupun tingkat rendah dengan kadar dan kualitas yang berbeda-beda. Di Indonesia, sumber tanin antara lain diperoleh dari jenis tanaman bakau atau akasia (Acacia $s p$ ), ekaliptus (Eucalyptus sp), pinus (Pinus $s p$ ) dan sebagainya. Tanin adalah polifenol alami yang selama ini banyak digunakan sebagai bahan perekat tipe eksterior terutama terdapat pada bagian kulit kayu. Tanin memiliki sifat antara lain dapat larut dalam air atau alkohol karena tanin banyak mengandung fenol yang memiliki gugus $\mathrm{OH}$, dapat mengikat logam berat, serta adanya zat yang bersifat anti rayap dan jamur (Carter et al., 1978 dalam (Risnasari, 2002).

Selain tanin, flavonoid, triterpenoid, dan saponin merupakan senyawa kimia 
yang berpotensi sebagai antivirus dan antibakteri (Robinson (1995) dalam (Setiawati, 2015), (Setiawati, Fitriana, \& Soedarmanto, 2017). Senyawa metabolit sekunder yang terkandung dalam ekstrak tumbuhan yang berpotensi sebagai antirayap antara lain alkaloid, flavonoid, triterpenoid, steroid, tanin dan saponin (Puteri et al., 2016). Keawetan alami kayu salah satunya ditentukan oleh peranan zat ekstraktif yang spesifik dari setiap jenis kayu, meskipun tidak semua zat ektraktif bersifat racun bagi organisnme perusak kayu (Da Silveira et al., 2017). Semakin tinggi kadar zat ekstraktif kayu, maka tingkat keawetan alami kayu juga cenderung meningkat.

Pada industri pengolahan kayu, khususnya industri penggergajian kayu ulin, menghasilkan limbah berupa serbuk gergajian kayu yang belum termanfaatkan secara optimal (Setiawati, 2015). Ekstrak kayu ulin mengandung berbagai senyawa kimia, yaitu alkaloid, flavonoid, triterpenoid, tanin dan saponin. Selain itu dengan proses ekstraksi menggunakan metanol diperoleh senyawa 1,2,3-trimethoxy-5-(2propenyl)-benzene sebesar $66 \%$ dan beberapa senyawa lainnya. 1,2,3trimethoxy-5-(2-propenyl)-benzene merupakan bahan aktif dalam farmakologi yang diaplikasikan sebagai antibakteri (Setiawati, 2015). Pemilihan kayu ulin sebagai bahan baku pengawet, juga dikarenakan kayu ulin termasuk kayu kelas awet I dan kayu kelas kuat I. Berdasarkan penelitian (Bakri, Fahriza, \& Cahyana, 2012), senyawa aktif kayu jati yang termasuk kayu kelas awet I dan kelas kuat I, mampu mengawetkan kayu durian dengan mortalitas rayap $100 \%$ dan retensi $17,01 \mathrm{mg} / \mathrm{cm}^{3}$. Penelitian lain juga menyebutkan bahwa zat ekstraktif kayu Kopo yang tergolong kayu kelas awet II serta kelas kuat I dengan fraksi etil asetat mampu meningkatkan mortalitas rayap hingga $100 \%$ pada minggu ketiga dengan konsentrasi 8\% (Mayangsari, 2008). Berdasarkan hasil penelitian ini, maka sangat dimungkinkan bahwa ekstrak kayu ulin dapat menjadi pengawet kayu dari serangan rayap tanah.

\section{BAHAN DAN METODE}

Bahan yang digunakan pada penelitian ini antara lain: serbuk kayu ulin (Eussiderxylon zwageri), kayu karet (Hevea brsiliensis Muell. Arg.), kayu sengon (Falcataria mollucana), dan cat kayu. Peralatan yang digunakan yaitu: kompor, penampung ekstrak, kaliper (micrometer), gelas piala, magnetic stirrer, termometer, oven, hot plate stirrer, rotary evaporator serta neraca analitik.

\subsection{Proses Ekstraksi Serbuk Gergajian Kayu}

Serbuk gergajian kayu ulin dicampur dengan pelarut air dengan rasio (b/v): $5 \%$; $10 \%$; 15\%; 20\%. Campuran tersebut dipanaskan hingga suhu $(\mathrm{T})=40^{\circ} \mathrm{C}$ selama $(\mathrm{t})=1$ jam, kemudian disaring menggunakan kain saring. Ekstrak yang telah diperoleh digunakan sebagai bahan pengawet. Untuk analisa fitokimia, ekstrak tersebut dipekatkan dengan evaporasi menggunakan rotary evaporator pada suhu $(\mathrm{T})=45^{\circ} \mathrm{C}$ hingga sisa $1 / 10$ dari volume awal ekstrak kemudian dicampur dan diaduk dengan maltodekstrin sebesar 10\% (b/v) diaduk menggunakan mixer hingga berbuih. Hasil yang diperoleh, dituang ke loyang dan dikeringkan dalam oven vakum $\left(T=40-45^{\circ} \mathrm{C}\right)$ hingga mengering. Ekstrak kering yang diperoleh dimasukkan kedalam desikator dan ditimbang hingga diperoleh berat konstan.

\subsection{Proses pengawetan kayu}

Setiap jenis kayu dipotong sesuai ukuran sampel uji $(0,5 \times 2,5 \times 2,5) \mathrm{cm}$, kemudian kayu dikeringkan (kering udara) hingga kadar air $\pm 20 \%$. Setelah kering udara, kayu - kayu tersebut diawetkan dengan perendaman menggunakan larutan ekstrak kayu ulin.

\subsection{Rancangan Percobaan (Amaliyah, 2018)}

1. Jenis Kayu yang diawetkan (a): kayu karet (a1), kayu sengon (a2)

2. Rasio ekstrak (b/v)-(b): 5\% (b1); 10\% (b2); 15\% (b3); 20\% (b4)

3. Jenis Perendaman(c): panas (c1), dingin (c2) 
4. Waktu Perendaman (d) :

a) perendaman panas (d1): (1 (d11), 2 (d12), 3 (d13)) jam;

b) perendaman dingin (d2):

$$
\text { (1 (d21), } 2 \text { (d22), } 3 \text { (d23)) hari }
$$

5. Pengulangan: 3 (tiga) kali.

Data-data tersebut dianalisa statistik menggunakan anova satu arah.

\subsection{Pengujian}

Pengujian ketahanan kayu terhadap rayap tanah dilakukan di Pusat Penelitian dan Pengembangan Hasil Hutan, Kementerian Lingkungan Hidup dan Kehutanan di Bogor. Metode pengujian mengacu pada SNI 7207:2014.

\section{HASIL DAN PEMBAHASAN}

Proses ekstraksi serbuk kayu ulin dilakukan dengan cara maserasi panas. Ekstrak kayu ulin larut dalam pelarut air ditandai dengan adanya perubahan warna pada air rendaman menjadi kecokelatan. Zat ekstraktif mudah larut dalam air dengan variasi konsentrasi 3-10\% berat kayu kering. Komposisi zat ekstraktif antara lain minyak, resin, lilin, tanin, gula, pati, dan warna lainnya (Dumanauw, 1992 dalam Kurniawan, 2013).

Berdasarkan Gambar 1, konsentrasi ekstrak mempengaruhi rendemen yang dihasilkan. Konsentrasi maksimum terekstraknya serbuk kayu adalah pada rasio pelarut dengan serbuk 20:2, dikarenakan makin banyak serbuk kayu ulin yang digunakan dan rendemen yang dihasilkan semakin menurun. Hal ini disebabkan larutan ekstrak telah mencapai kondisi jenuh, sehingga ekstrak tidak dapat terlarut lagi ke dalam pelarut. Dengan waktu ekstrak yang sama, yaitu 1 jam, partikel ekstrak yang berpindah ke dalam pelarut berada dalam kesetimbangan dengan fase padat. Larutan jenuh merupakan larutan dimana zat terlarut (molekul atau ion) telah maksimum pada suhu tertentu (Anonim, 2018). Jumlah serbuk kayu pada rasio (b/v) $15 \%$ dan $20 \%$ adalah terlalu besar, sehinga ekstrak yang tidak dapat keluar terlarut secara maksimal dalam air dikarenakan kondisi jenuh tersebut. Wati, Musadi, Khumaira, \& Amelia (2017) menyatakan bahwa semakin banyak jumlah pelarut yang digunakan, maka kontak antara bahan simplisia dengan pelarut semakin banyak pula, sehingga ekstrak yang keluar saat ekstraksi semakin banyak. Menurut Zhang, Lin, \& Ye (2018), makin besar rasio pelarut dengan padatan bahan baku, maka rendemen ekstrak makin meningkat. Namun apabila rasio pelarut dengan padatan bahan baku terlalu tinggi, maka pelarut akan berlebih dan akan memerlukan waktu yang lebih banyak untuk memekatkan ekstrak.

Berdasakan hasil uji fitokimia, senyawa metabolit sekunder dalam ekstrak kayu ulin secara berturut-turut antara lain alkaloid, tanin, saponin, flavonoid dan total fenolik (Gambar 2). Kandungan tertinggi adalah senyawa fenolik, yaitu sebesar $15,36 \%$. Kelima kandungan fitokimia ini merupakan bahan yang berpotensi sebagai fungisida, herbisida maupun insektisida, seperti halnya telah disebutkan oleh Tumanggor (2018), berbagai jenis tanaman berpotensi sebagai insektisida nabati dikarenakan mengandung metabolit sekunder saponin, tanin, alkaloid, alkenil, fenol, flavonoid, dan terpenoid. Siregar, Dalimunthe, Sembiring, Andriyanto, Darwin, dan Barus, (2015) juga menyatakan bahwa senyawa flavonoid, saponin, steroid dan polifenol dalam daun Coleus amboinicus, Naruzawa \& Papa (2011), senyawa polifenol dan alkaloid dalam daun Myracrodrun urundeuva, Lafoensia pacar dan Caryocar brasiliense, mampu menghambat penyebab penyakit pada tanaman karet.

Beberapa senyawa metabolit sekunder diduga mampu menghambat serangan faktor biologis. Alkaloid memiliki kandungan senyawa penolak serangga serta anti jamur. Flavonoid memiliki fungsi sebagai antimikroba dan antivirus terhadap serangga. Senyawa fenolik, triterpenoid, alkaloid, dan steroid pada tanaman merupakan senyawa aktif sebagai pengendali hama. Senyawa ini bersifat toksin terhadap menghambat pola makan, antiparasit dan pestisida (Robinson (1991) 


\title{
Komposisi Fitokimia (\%) b/b
}

\author{
Tanin Total Alkaloid $\square$ Saponin $\square$ Total Flavonoid $\square$ Total Fenol
}

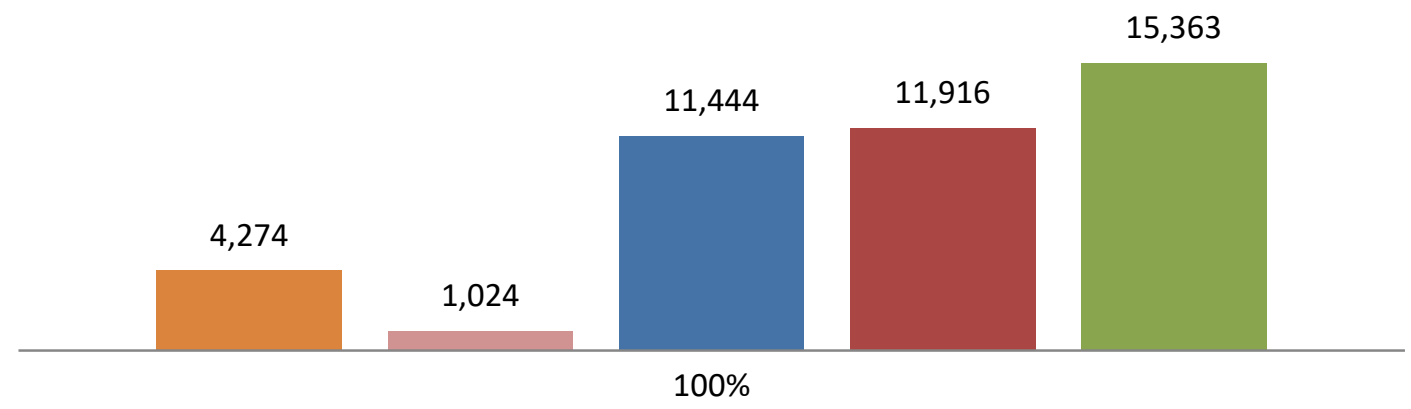

Gambar 2. Komposisi Fitokimia Ekstrak Kayu Ulin

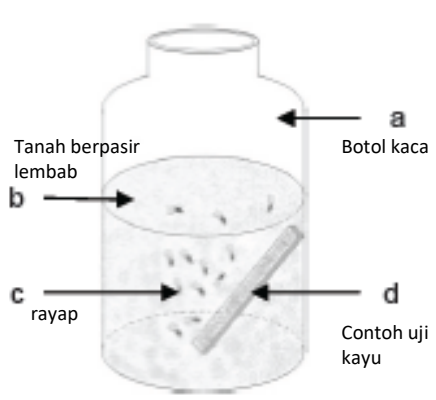

(a)

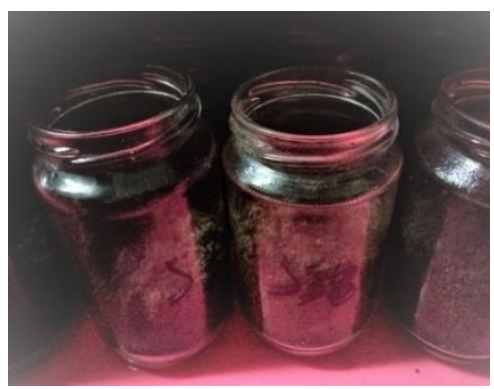

(b)

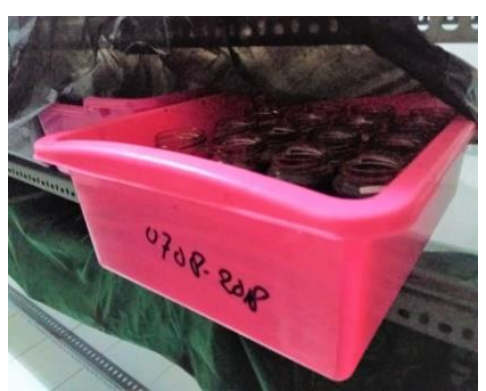

(c)

Gambar 3. Proses Pengujian Ketahanan Kayu Terhadap Rayap Tanah (a) Sesuai SNI 7207:2014; (b) dan (c) Pengujian Pengawet Alami Ekstrak Kayu Ulin Terhadap Serangan Rayap Tanah Terhadap Sesuai SNI 7207:2014

dan Harborne (1987) dalam Pratiwa, Diba, \& Wahdina (2015).

Pada penelitian ini dilakukan pengawetan menggunakan ekstrak kayu ulin yang diaplikasikan pada kayu karet dan kayu sengon. Kayu yang telah diawetkan kemudian diuji terhadap serangan rayap tanah sebagai salah satu parameter uji keawetan kayu (Gambar 3). Pada Gambar 4 sampai dengan Gambar 7 menjelaskan mengenai pengaruh konsentrasi ekstrak dan waktu perendaman terhadap pengurangan berat kayu setelah diumpankan ke rayap tanah.

Penurunan berat kayu merupakan salah satu indikator dari efektivitas ekstrak sebagai bahan pengawet terhadap kayu yang diawetkan, yaitu kemampuan bahan ekstrak dalam mengurangi serangan rayap setelah diaplikasikan terhadap contoh uji. Semakin kecil persen penurunan berat, menunjukkan semakin efektif ekstrak tersebut sebagai pengawet (Riska, Erniwati, \& Hapid, 2014). 


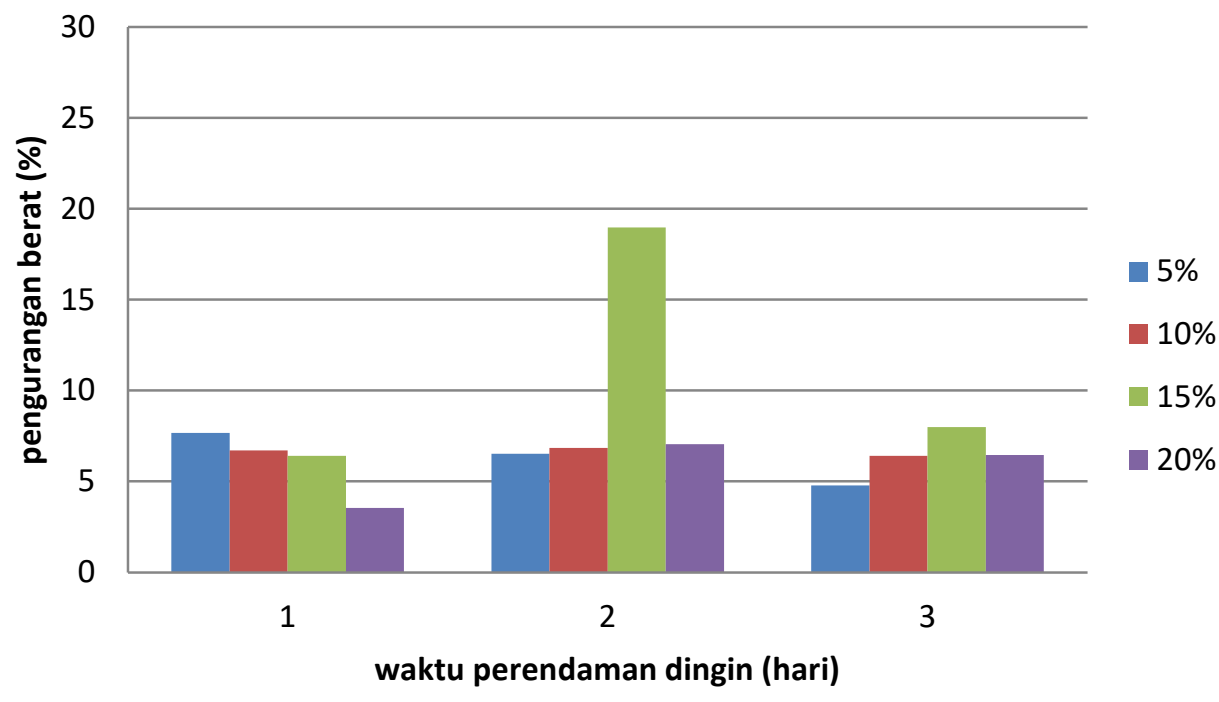

Gambar 4. Pengaruh Konsentrasi dan Waktu Terhadap Pengurangan Berat (Perendaman Dingin) Kayu Karet

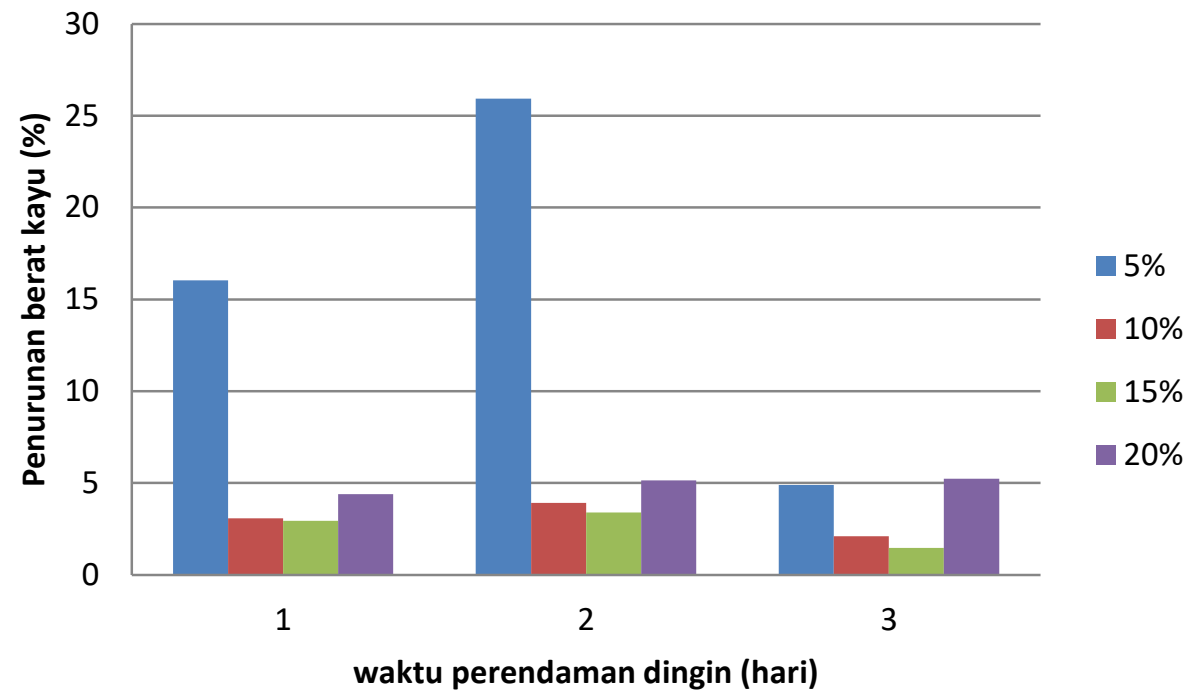

Gambar 5. Pengaruh Konsentrasi dan Waktu Terhadap Pengurangan Berat (Perendaman Dingin) Kayu Sengon

Pada Gambar 4 dapat dilihat bahwa pada perendaman dingin kayu karet, pengurangan berat yang terbesar adalah pada konsentrasi $15 \%$ selama 2 (dua) hari dengan penurunan sebesar $18,97 \%$. Sedangkan penurunan berat terkecil adalah pada perendaman konsentrasi $20 \%$ selama 1 (satu) hari, yaitu sebesar 3,55\%. Hal ini berarti pada perendaman dingin kayu karet menggunakan 20\% ekstrak selama 24 jam adalah yang paling efektif, dikarenakan memberikan daya awet yang lebih tinggi dibandingkan dengan perlakuan yang lain, yang dibuktikan dengan penurunan berat kayu terkecil setelah diumpankan ke rayap tanah. Artinya ekstrak kayu ulin mampu meracuni rayap tanah sehingga kayu karet yang telah diawetkan tidak disukai oleh rayap tanah yang diumpankan. Menurut Riska et al. (2014), adanya racun dalam ekstrak menyebabkab rayap tanah tidak leluasa 
memakan komponen pada kayu, sehingga rayap tidak dapat bertahan hidup, karena makanan yang tersedia telah teracuni oleh pengawet.

Berdasarkan uji anova satu arah, perlakuan yang diberikan terhadap kayu karet berpengaruh secara signifikan, dikarenakan dengan adanya pengawetan menggunakan ekstrak kayu ulin memberikan pengaruh peningkatan daya awet kayu, dibandingkan tanpa diawetkan (Tabel 1).

Pada Gambar 5 dapat dilihat bahwa pada perendaman dingin kayu sengon, pengurangan berat yang terbesar adalah pada konsentrasi $5 \%$ selama 2 (dua) hari dengan penurunan sebesar 25,92\%. Sedangkan penurunan berat terkecil adalah pada perendaman konsentrasi $15 \%$ selama 3 (tiga) hari, yaitu sebesar 1,46\%. Artinya pada perendaman dingin kayu sengon menggunakan $15 \%$ ekstrak selama 72 jam adalah yang paling baik. Dikarenakan memberikan daya awet yang lebih tinggi dibandingkan dengan perlakuan yang lain, yang dibuktikan dengan penurunan berat kayu terkecil setelah diumpankan ke rayap tanah. Hal ini membuktikan bahwa pada perendaman dingin, ekstrak kayu ulin efektif meningkatkan daya awet kayu sengon pada kondisi tersebut, dikarenakan ekstrak kayu ulin mampu meracuni rayap tanah sehingga kayu sengon yang telah diawetkan tidak disukai oleh rayap tanah yang diumpankan.

Namun demikian berdasarkan uji anova satu arah, perlakuan yang diberikan terhadap kayu sengon tidak berpengaruh secara signifikan, karena berdasarkan ulangan hasil uji, baik diawetkan maupun tidak diawetkan, kayu sengon mengalami penurunan berat yang tidak beraturan. Hasil tersebut, perlu diteliti lebih lanjut.

Pada Gambar 6 dapat dilihat bahwa pada perendaman panas kayu karet, pengurangan berat yang terbesar adalah pada konsentrasi $5 \%$ selama 0,5 (setengah) jam dengan penurunan sebesar $9,78 \%$. Sedangkan penurunan berat terkecil adalah pada perendaman konsentrasi $5 \%$ selama 2 (dua) jam, yaitu sebesar $3,17 \%$.

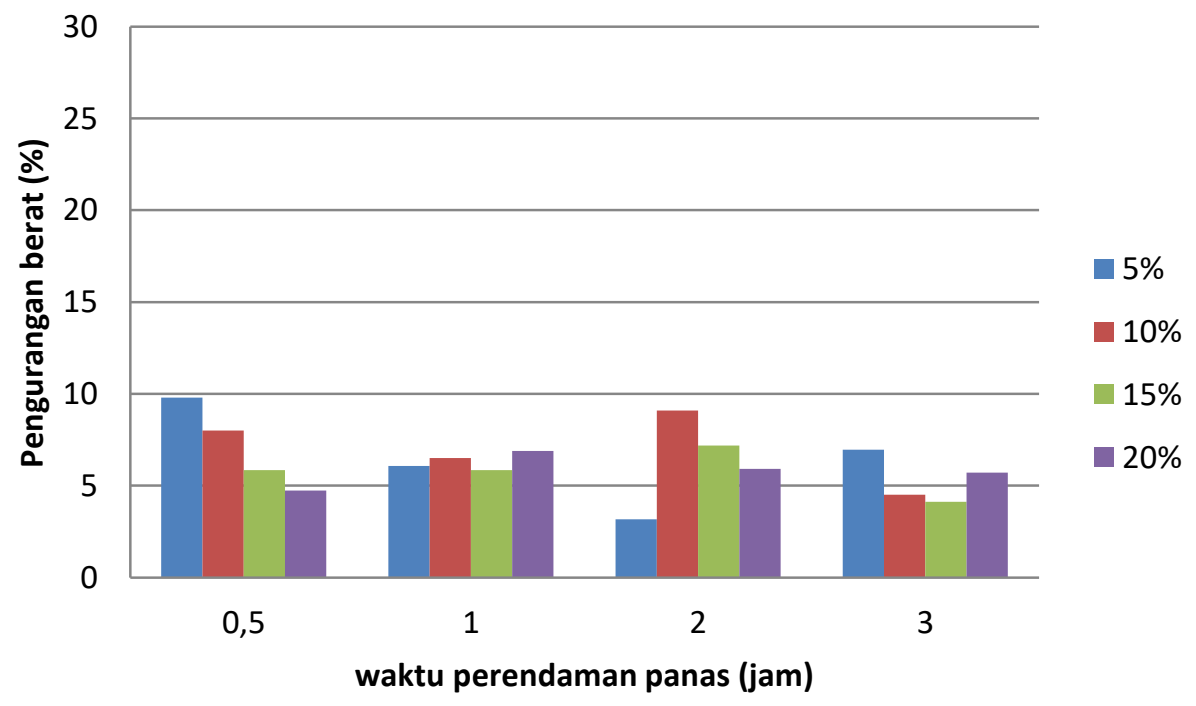

Gambar 6. Pengaruh Konsentrasi dan Waktu Terhadap Pengurangan Berat (Perendaman Panas) Kayu Karet 


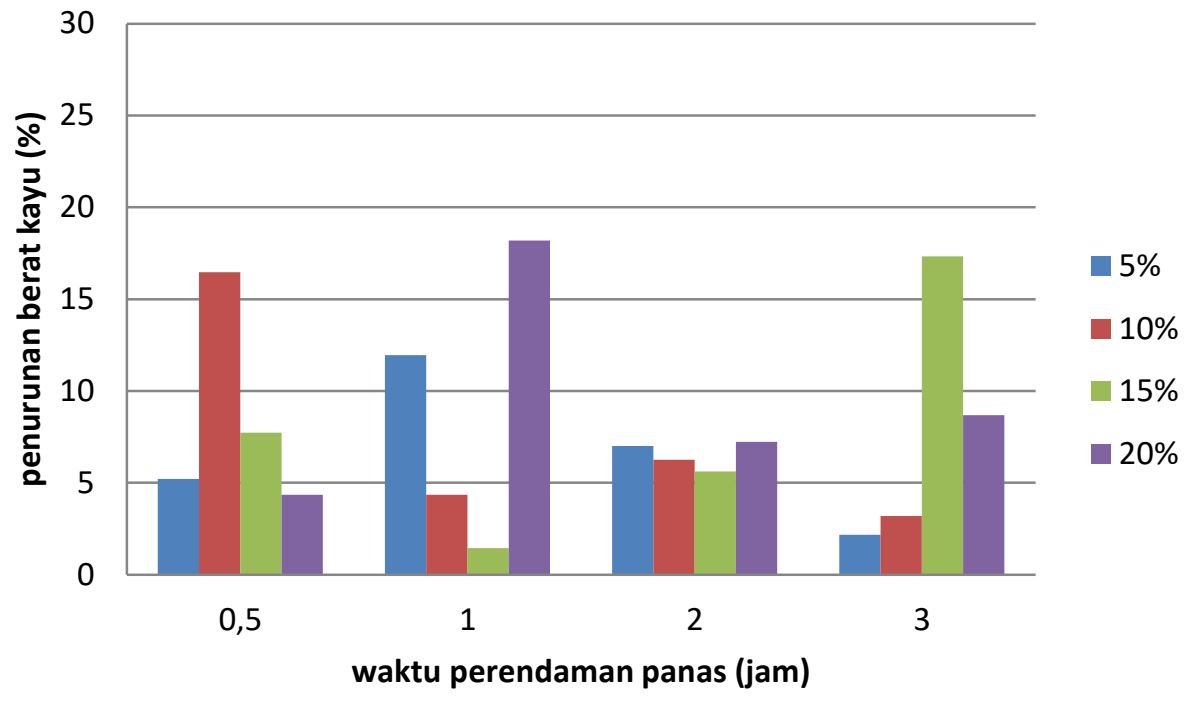

Gambar 7. Pengaruh Konsentrasi dan Waktu Terhadap Pengurangan Berat (Perendaman Panas) Kayu Sengon

Tabel 1. Hasil Uji Kontrol Sampel serta Hasil Ketahanan terhadap Rayap Tanah

\begin{tabular}{llcccc}
\hline $\begin{array}{l}\text { Jenis } \\
\text { kayu }\end{array}$ & $\begin{array}{c}\text { Konsentrasi (\%) } \\
\text { dan Jenis } \\
\text { Perendaman }\end{array}$ & $\begin{array}{c}\text { Kode } \\
\text { Kayu }\end{array}$ & Pengurangan Berat (\%) & $\begin{array}{c}\text { Klasifikasi } \\
\text { Ketahanan } \\
\text { Kayu }\end{array}$ & $\begin{array}{c}\% \\
\text { Mortalitas }\end{array}$ \\
\hline Karet & Kontrol (+) & $\mathrm{K}+$ & 9,69 & III & 42,5 \\
\hline & Pengawetan dingin & $\mathrm{K} 1-\mathrm{K} 12$ & $3,547(\mathrm{~K} 10)-18,974(\mathrm{~K} 8)$ & II -V & 100 \\
\hline Sengon & Pengawetan panas & $\mathrm{K} 13-\mathrm{K} 28$ & $3,167(\mathrm{~K} 15)-9,785(\mathrm{~K} 13)$ & II-III & 100 \\
& Kontrol (+) & $\mathrm{S}+$ & 14,768 & IV & 10 \\
\hline & Pengawetan dingin & $\mathrm{S} 1-\mathrm{S} 12$ & $1,459(\mathrm{~S} 9)-25,919(\mathrm{~S} 2)$ & $\mathrm{I}-\mathrm{V}$ & 100 \\
\hline & Pengawetan panas & $\mathrm{S} 13-\mathrm{S} 28$ & $1,436(\mathrm{~S} 22)-18,198(\mathrm{~S} 26)$ & $\mathrm{I}-\mathrm{IV}$ & 100 \\
\hline
\end{tabular}

Pada Gambar 7 dapat dilihat bahwa pada perendaman panas kayu sengon, pengurangan berat yang terbesar adalah pada konsentrasi $20 \%$ selama 1 (satu) jam dengan penurunan sebesar 18,20\%. Sedangkan penurunan berat terkecil adalah pada perendaman konsentrasi $15 \%$ selama 1 (satu) jam, yaitu sebesar 1,35\%.

Berdasarkan pengurangan berat kayu karet dan kayu sengon setelah diumpankan ke rayap tanah (Coptotermes curvignathus Holmgren) seperti pada Gambar 4 sampai Gambar 7, dapat diketahui bahwa jika dibandingkan dengan sampel kontrol (+) pada Tabel 1, di mana kontrol (+) adalah kayu yang diperlakukan tanpa pengawetan. Ketahanan kayu karet maupun sengon dapat meningkat hingga 2 (dua) tingkat dengan pengawetan menggunakan ekstrak kayu ulin. Untuk klasifikasi ketahanan kayu terhadap rayap tanah dapat dilihat Pada Tabel 2.

Tabel 2. Klasifikasi Ketahanan Kayu Terhadap Rayap Tanah

\begin{tabular}{ccc} 
Kelas & Ketahanan & $\begin{array}{c}\text { Penurunan } \\
\text { Berat }(\%)\end{array}$ \\
\hline I & Sangat tahan & $<3,5$ \\
\hline II & Tahan & $3,5-7,40$ \\
\hline III & Agak tahan & $7,50-10,8$ \\
\hline IV & Tidak tahan & $10,9-18,9$ \\
\hline V & Sangat tidak tahan & $>18,9$ \\
\hline
\end{tabular}


Secara keseluruhan, berdasarkan hasil uji statistik uji anova satu arah untuk perlakuan pada kayu karet, memberikan pengaruh yang signifikan terhadap penurunan berat kayu. Penurunan berat yang paling berbeda nyata adalah pada perlakuan perendaman dingin dengan konsentrasi ekstrak 15\% selama 2 hari (penurunan berat tertinggi) dan perendaman panas konsentrasi $5 \%$ selama 2 jam (penurunan berat terendah). Sedangkan untuk perlakuan terhadap kayu sengon tidak memberikan pengaruh yang signifikan terhadap penurunan berat kayu. Penurunan berat paling rendah pada kayu sengon terjadi pada perendaman panas konsentrasi $15 \%$ dengan waktu perendaman 1 jam.

Pada pengujian ini juga dianalisis derajat serangan serta mortalitas rayap tanah terhadap kayu yang telah diawetkan menggunakan ekstrak kayu ulin. Nilai mortalitas rayap adalah $100 \%$ baik pada konsentrasi $5 \%$ hingga $20 \%$. Artinya ekstrak kayu ulin bersifat racun bagi rayap tanah, sehingga menyebabkan kematian keseluruhan rayap yang diumpankan. Sedangkan pada kontrol (+) mortalitas rayap masih di bawah $50 \%$ (Tabel 1 ). Hal ini sesuai dengan hasil penelitian yang dilakukan oleh (Kadir, 2017) dan Oramahi, Diba, \& Nurhaida (2014) yang menyatakan bahwa kematian rayap tanah disebabkan racun yang terkandung dalam pengawet yang diaplikasikan terhadap kayu. Kandungan fenolik, alkaloid, flavonoid, saponin, serta tanin yang terkandung dalam ekstrak kayu ulin inilah yang menjadi racun bagi rayap tanah.

Kelemahan dari pengawetan menggunakan ekstrak ulin ini, aroma dari ekstrak tidak membuat rayap tanah menjauh dari kayu, sehingga kayu masih dimakan oleh rayap tanah. Ini dibuktikan dengan adanya pengurangan berat kayu dan adanya lubang bekas serangan rayap setelah diumpankan selama 4 minggu. Artinya, rayap tanah tidak langsung mati ketika diumpankan ke kayu yang telah diawetkan, akan tetapi, masih hidup dan memakan kayu. Akan tetapi selama rentang waktu pengujian, secara bertahap rayap mati, sehingga saat pengamatan pada akhir masa pengujian, rayap tanah mati seluruhnya.

\section{KESIMPULAN DAN SARAN}

Pada uji ketahanan terhadap serangan rayap tanah, ekstrak kayu ulin mampu menaikkan klasifikasi ketahanan kayu karet dari kelas IV ke kelas II, dan kayu sengon dari kelas IV ke kelas I, meskipun masih ada serangan pada kayu karet dan kayu sengon. Mortalitas rayap tanah yang diumpankan ke kayu karet dan kayu sengon adalah sebesar $100 \%$ baik $5 \%$ hingga $20 \%$.

Pengawetan kayu sengon serta kayu karet menggunakan ekstrak kayu ulin perlu diteliti lebih lanjut, untuk mengetahui secara lebih detail kecenderungan penurunan berat kayu dan tingkat mortalitas rayap tanah.

\section{UCAPAN TERIMAKASIH}

Kami mengucapkan terima kasih kepada Kepala Baristand Industri Banjarbaru, Ir. Lies Indriati, anggota tim Ratri Yuli Lestari, S.Hut, M.Env, Budi Tri Cahyana, ST, Saibatul Hamdi, MP, Nurmilatina, S.Si, M. Listianto Raharjo, S.T serta kepada Bapak Agus Ismanto dan Bapak Djarwanto yang telah membantu pengujian dan konsultasi mengenai organisme perusak kayu, dan semua pihak yang telah membantu pelaksanaan penelitian ini hingga dapat terlaksana dan selesai pada waktunya.

\section{DAFTAR PUSTAKA}

Amaliyah, D. M. (2018). Peningkatan Kayu Kelas Awet Rendah Menggunakan Pengawet Alami Ekstrak Kayu Ulin (Eusideroxylon zwageri) (Laporan Akhir Litbangyasa). Balai Riset dan Standardisasi Industri Banjarbaru. Banjarbaru. Indonesia

Anonim. (2018). Solvasi. Retrieved from wikipedia website: https://id.wikipedia.org/wiki/Solvasi

Bakri, S., Fahriza, A., \& Cahyana, B. T. (2012). Serbuk Gergajian Kayu Jati (Tectona grandis) sebagai Bahan 
Pengawet Kayu Durian (Durio zebethinus). Jurnal Riset Hasil Hutan, 4(2), 1-5.

Da Silveira, A. G., Santini, E. J., Kulczynski, S. M., Trevisan, R., Wastowski, A. D., \& Gatto, D. A. (2017). Tannic extract potential as natural wood preservative of Acacia mearnsii. Annals of the Brazilian Academy, 89(4), 3031-3038. https://doi.org/http://dx.doi.org/10.1590 /0001-3765201720170485

Kadir, R. (2017). Toxic effects of three selected Malaysian timbers plant extracts against subterranean termites. Maderas: Ciencia $y$ Tecnologia, 19(4), 417-432. https://doi.org/10.4067/S0718221X2017005000035

Kurniawan, A. (2013). Uji Ketahanan Kayu Karet (Hevea braziliensis) terhadap Serangan Rayap Tanah dengan menggunakan Rendaman Kayu Ulin (Eusideroxylon zwageri) (Karya IImiah Diploma III). Politeknik Pertanian Negeri Samarinda. Samarinda. Indonesia.

Mayangsari, R. (2008). Sifat Anti Rayap Zat Ekstraktif Kayu Kopo (Eugenia cymosa Lamk) terhadap Rayap Tanah (Coptotermes curvignathus Holmgren) (Skripsi Sarjana). Institut Pertanian Bogor. Bogor. Indonesia

Meidianto, A., Jayuska, A., \& Wibowo, M. A. (2019). Bioaktivitas Antirayap Ekstrak Kayu Gaharu Buaya (Aetoxylon sympetalum) Terhadap Rayap Tanah (Coptotermes sp). Jurnal KImia Khatulistiwa, 8(1), 11-16.

Naruzawa, E. S., \& Papa, M. F. S. (2011). Antifungal activity of extracts from Brazilian Cerrado plants on Colletotrichum gleosporioidesand Corynespora cassiicola. Revista Brasiliera de Plantas Medicinais, 13(4), 408-412.

Oramahi, H. A., Diba, F., \& Nurhaida. (2014). New Bio Preservatives from Lignocelluloses Biomass Bio-oil for Anti Termites Coptotermes Curvignathus Holmgren. Procedia Environmental Sciences, 20, 778-784. https://doi.org/10.1016/j.proenv.2014.0
3.094

Pratiwa, C., Diba, F., \& Wahdina. (2015). Bioaktivitas Ekstrak Etanol Buah Mengkudu (Morinda citrifolia L.) terhadap Rayap Tanah (Coptotermes curvignathus Holmgren). Jurnal Hutan Lestari, 3(2), 227-233.

Puteri, I. T., Jayuska, A., \& Alimuddin, A. H. (2016). Aktivitas Antirayap Daun Gaharu ( Aquilaria malaccensis Lam .). Jurnal KImia Khatulistiwa, 5(2), 614. Retrieved from http://jurnal.untan.ac.id/index.php/jkkm ipa/article/view/13391/12056

Riska, Erniwati, \& Hapid, A. (2014). Retensi Bahan Pengawet Ekstrak Daun Tembelekan (Lantana Camara L) pada Beberapa Jenis Kayu dan Efektifitasnya Terhadap Serangan Rayap Tanah (Coptotermes sp.). Warta Rimba, 2(2), 125-132.

Risnasari, I. (2002). Tanin. In Tanin. Medan: USU Digital Library.

Setiawati, E. (2015). Pemanfaatan Serbuk Kayu Ulin (Eussiderxylon zwageri) Sebagai Bahan Aktif Anti Bakteri untuk Pembuatan Obat Herbal. Banjarbaru.

Setiawati, E., Fitriana, M., \& Soedarmanto, H. (2017). Isolation and Antimicrobial Activities of Ironwood Extracts (Euxideroxylon zwageri) for Mouthwash Formulation. In B. Nugroho, I. D. M. F. Septayana, \& T. C. Krisna (Eds.), International Indonesian Student Conference Edition (pp. 56-67). Retrieved from www.isjournal.org

Siregar, T. H. S., Dalimunthe, C. I., Sembiring, Y. R. V., Andriyanto, M., Darwin, H. S., \& Barus, D. A. (2015). Identifikasi dan uji antagonis metabolit sekunder bangun- bangun (Coleus amboinicus) sebagai fungisida nabati untuk mengendalikan penyakit jamur akar putih (Rigidoporus microporus) (Laporan Balai Penelitian Sungai Putih). Deli Serdang. Indonesia.

Tumanggor, W. (2018). Uji Kemampuan Ekstrak Langge (Homalomena propinqua Ridl ) untuk Pengendalian Rayap Tanah (Coptotermes curvignathus) (Skripsi Sarjana). 
Universitas Sumatera Utara. Medan. Indonesia.

Wati, I., Musadi, M. R., Khumaira, N. S., \& Amelia, A. R. (2017). Pengaruh Konsentrasi Pelarut, Waktu Ekstraksi, Dan Nisbah Bahan Baku Dengan Pelarut Terhadap Ekstraksi Kunyit Kuning (Curcuma longa L.). Jurnal ITEKIMA, 2(1), 52-60.

Wibaldus, Jayuska, A., \& Ardiningsih, P. (2016). Bioaktivitas Minyak Atsiri Kulit Buah Jeruk Nipis (Citrus aurantifolia) terhadap Rayap Tanah (Coptotermes sp.). 5(1), 44-61. Retrieved from http://jurnal.untan.ac.id/index.php/jkkm ipa/article/view/13378/12041

Zhang, Q. W., Lin, L. G., \& Ye, W. C. (2018). Techniques for extraction and isolation of natural products: a comprehensive review. Chinese Medicine, 1-26. https://doi.org/10.1186/s13020-0180177-x 
Jurnal Riset Industri Hasil Hutan Vol.11, No.2, Des 2019: 85 - 96 